\title{
Impact of different sources of donor cells upon the nuclear transfer efficiency in Chinese indigenous Meishan pig
}

\author{
Z. Hua ${ }^{1}$, G. Xu' ${ }^{2}$, X. Liu' ${ }^{1}$, Y. Bi ${ }^{1}$, H. Xiao ${ }^{1}$, W. Hua ${ }^{1}$, L. Li ${ }^{1}$, L. Zhang ${ }^{1}$, \\ H. $\operatorname{Ren}^{1}, X$. Zheng ${ }^{1}$ \\ ${ }^{1}$ Hubei Key Lab of Animal Embryo Engineering and Molecular Breeding, \\ Hubei Academy of Agricultural Sciences, Wuhan City, Hubei province, 430064,China \\ ${ }^{2}$ Agriculture and Animal Husbandry College of Qinghai University, \\ Xining, Qinghai province, China
}

\begin{abstract}
Somatic cell nuclear transfer (SCNT) is currently the most efficient and precise method to generate genetically tailored pig models for both agricultural and biomedical research. However, its efficiency is crucially dependent on the source of nuclear donor cells. In this study, we compared the cloning efficiency by using three lines of donor cells that are derived from fetal, newborn and adult fibroblasts of Chinese indigenous Meishan pig. We showed that cleavage rate and blastocyst formation rate of the reconstructed embryos were not significantly different between the fetal $(80.7 \%$ and $15.6 \%$ ) and newborn ear skin (77.5\% and 12.3\%) fibroblast groups ( $>0.05)$, but in both groups these indices were significantly higher than that found in the adult ear skin $(70.5 \%$ and $8.8 \%$; $\mathrm{p}<0.05)$. Reconstructed embryos derived from fetal, newborn, and adult ear skin fibroblasts were transferred to four surrogates, respectively. For the fetal, newborn, and adult ear skin fibroblasts, the number of pregnancies were two $(50.0 \%)$, two $(50.0 \%)$, and one $(25.0 \%)$, respectively, and the number of deliveries were two $(50.0 \%)$, one $(25.0 \%)$, and zero $(0.0 \%)$, respectively. Seven and two cloned piglets were obtained from the fetal and newborn ear skin fibroblasts respectively, while no piglets were obtained from the adult ear skin fibroblasts. Two cloned piglets from the newborn ear skin fibroblasts died shortly after birth because of neonatal asphyxia caused by dystocia. The birth weights of the piglets derived from the fetal and newborn ear skin fibroblasts were 1230.5 and $1310.0 \mathrm{~g}$, respectively, which were statistically insignificant $(\mathrm{p}>0.05)$, but both were significantly higher than that of the control groups $(\mathrm{p}<0.05)$. Microsatellite analyses demonstrated that the genotypes of all cloned piglets were identical to their donor cells. Therefore, cloned pigs were successfully produced using two sources of donor cells isolated from the fetal and newborn ear skin fibroblasts of Meishan piglet, and indicating a better cloning efficiency than that obtained from adult fibroblasts. We concluded that the nuclear donor cell lines have significant impact on the developmental competence of cloned embryos as well as on the cloning efficiency of Meishan pig.
\end{abstract}

Key words: Meishan pig, cloned piglet, somatic cell nuclear transfer, fibroblasts. 


\section{Introduction}

The first report of cloned piglets by somatic cell nuclear transfer (SCNT) was published in 2000 (Betthauser et al. 2000), three years after the birth of Dolly, which was the first mammal to have been cloned from a somatic cell (Wilmut et al. 1997). This method has been successfully applied in many other animals like calf (Kato et al. 1998), mouse (Wakayama et al. 1998), goat (Baguisi et al. 1999), horse (Galli et al. 2003), buffalo (Shi et al. 2007), camel (Wani et al. 2010) and so on. The utilizing of SCNT could rapidly copy a large number of animals with excellent quality and quantity traits (Prather et al. 2003). However, due to the experimental procedure is cumbersome, and there are many factors that can affect the efficiency of. SCNT. As their major anatomical and physiological characteristics are similar to our humans, transgenic pigs have gained importance in the field of biomedical research (Swindle et al. 1998). But the technology of pig cloning was developed in a time frame relatively short since Dolly and similar to that applied in other species (Galli et al. 2003), and the success rate of remains lower than in other species (Muenthaisong et al. 2011). Therefore, to improve the efficiency of somatic cell nuclear transfer has become a hot spot of current research.

The first cloned animal was produced from terminally differentiated mammary epithelial cells in sheep (Wilmut et al. 1997). After that many primary cell lines established after passaging a primary culture were used for SCNT, with differences regarding the cell type including fetal and adult fibroblasts (Arat et al. 2002), cumulus (Wakayama et al. 1998), neurons (Zawada et al. 1998) and oviduct cells (Kato et al. 1998). Accumulated evidence was shown that the donor cells from different tissue or cell types vary in competence of reprogramming and efficiency of nuclear transfer (Powell et al. 2004). Some researches recently suggest that the passage number of the donor cells also affects the success of SCNT (Juan et al. 2014). Usually, donor cells derived from the female genital organs, such as cumulus, granulosa and oviduct epithelial cells seem better than other cells to support the development to term of SCNT embryos (Gong et al. 2004). Moreover, previous studies have shown that individual differences of donor cell types greatly influence the development of SCNT embryos, even if they were derived from the same tissue and cultivated under the same conditions (Kato et al. 2000). These observations suggest that individual genetic characteristics may play an important role in the reprogramming of a donor nucleus in the cytoplasm of the recipient cell. Therefore, choosing an appropri- ate nuclear donor cell line is undoubtedly an important component for the SCNT process. However, due to the extreme low cloning efficiency, it was difficult to make a rigorous assessment of the impact of nuclear donor cell types on overall SCNT success in most previous studies.

The present study investigated the developmental competence of SCNT embryos derived from different donor cells were as well as the cloning efficiency of Meishan pig. We used donor cells derived from fetal, newborn, and adult fibroblasts to establish the nuclear transfer technology system and obtain cloned pig offspring by SCNT. We assessed the impact effect on pregnancy and delivery rates as well as numbers of born, live and healthy offspring.

\section{Materials and Methods}

DPBS was purchased from Gibco Company. PMSG and hCG were from Ning Bo Hormone Products Factory in China, and other chemical reagents used for oocyte maturation, activation and embryo culture were purchased from Sigma Chemical Co. (St. Louis, MO, USA) unless otherwise noted.

\section{Preparation of donor cells}

Fetal fibroblast cells were isolated from pig fetuses on day 40 of gestation. The heads and internal organs were removed using iris scissors and forceps. The remnants were washed three times with DPBS, the carcass was minced with a surgical blade on a $100-\mathrm{mm}$ culture dish. The minced fetal tissues were dissociated in Dulbecco modified Eagle medium (DMEM, Gibco) supplemented with $0.25 \%(\mathrm{w} / \mathrm{v})$ trypsin-EDTA (Life Technologies) containing at 39 for 1 to $2 \mathrm{~h}$. Trypsinized cells were washed once by centrifugation at $1000 \mathrm{rpm}$ for $5 \mathrm{~min}$ and subsequently seeded into $100-\mathrm{mm}$ plastic culture dishes. Seeded cells were cultured for 6 to 8 days in DMEM supplemented with $10 \%$ (v/v) fetal bovine serum (FBS; Hyclone) and $10, \mathrm{~g} / \mathrm{mL}$ of penicillin-streptomycin solution (Sigma-Aldrich Corp.) at 39 in a humidified atmosphere of $5 \% \mathrm{CO}_{2}$ and $95 \%$ air. After removal of unattached clumps of cells or explants, attached cells were further cultured until confluent, and then passaged and frozen in DMEM containing 20\% FBS and 10\% dimethylsulfoxide for future use.

Ear tissues were collected from a newborn piglet and an adult pig of Meishan pig. The fibroblasts were isolated and cultured using the same procedure as described above. 

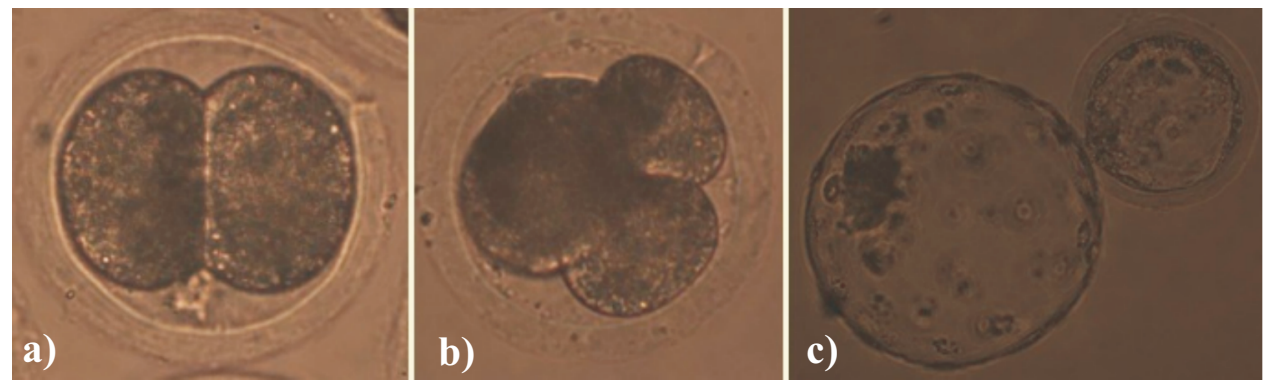

Fig. 1. In vitro development of cloned embryos. (a) 2-cell, (b) 4-cell, and (c) blastocyst.

\section{In vitro maturation of oocytes}

Ovaries were collected at local slaughterhouse and transported to the laboratory in $0.9 \%(\mathrm{w} / \mathrm{v}) \mathrm{NaCl}$ solution with antibiotics at 37 and maintained at this temperature. The ovaries were washed 3 to 5 times with $\mathrm{NaCl}$ solution (37) until aspiration. Cumulus oocyte complexes were obtained from follicles $3 \mathrm{~mm}$ to $6 \mathrm{~mm}$ in diameter using a 16-gauge needle connected to a $10 \mathrm{~mL}$ disposable syringe. After washing four times with DPBS containing $0.1 \%(\mathrm{w} / \mathrm{v})$ polyvinyl alcohol, oocytes were washed three times with culture medium. The oocytes were cultured in maturation medium (mTCM199) with PMSG (10 IU/mL), HCG (10 IU/mL), $3.05 \mathrm{mmol} / \mathrm{L}$ glucose, $0.91 \mathrm{mmol} / \mathrm{L}$ sodium pyruvate, $0.57 \mathrm{mmol} / \mathrm{L}$ cysteine and $10 \%$ porcine follicular fluid (pFF) for $22 \mathrm{~h}$ at $38.5 \mathrm{in}$ an atmosphere with $5 \% \mathrm{CO}_{2}$, then the oocytes were cultured without hormonal supplements for additional $22 \mathrm{~h}$. The oocytes matured in vitro for $42 \sim 44 \mathrm{~h}$ and the cumulus cells were completely removed from the oocytes by treatment with $0.1 \%$ hyaluronidase and pipetting. Oocytes with extruded the first polar body were judged mature and used then for nuclear transfer.

\section{Nuclear transfer}

The procedures of SCNT were performed as described previously (Wang et al. 2011). After culturing for $38 \mathrm{~h}$ to $42 \mathrm{~h}$, oocytes with expanded cumulus cells were briefly treated with $0.1 \%(\mathrm{w} / \mathrm{v})$ hyaluronidase and pipetting. Oocytes extruding the first polar body with uniform cytoplasm were cultured in NCSU23 medium supplemented with $0.1 \mu \mathrm{g} / \mathrm{mL}$ demecolcine, $0.05 \mathrm{M}$ sucrose, and $4 \mathrm{mg} / \mathrm{mL}$ bovine serum albumin (BSA) for $0.5 \mathrm{~h}$ to $1 \mathrm{~h}$. The first polar body and the small amount adjacent cytoplasm (approximately $1 / 4$ cytoplasm) were aspirated with a glass pipette (approximately $20 \mu \mathrm{m}$ in diameter) in DPBS microdrops supplemented with $7.5 \mu \mathrm{g} / \mathrm{mL}$ cytochalasin B (CB) and $10 \%$ FBS. Fetal, newborn, and adult ear skin fibroblasts of the fourth to ninth passages from Meishan pig were handled with $0.5 \%$ FBS serum starvation for $48 \mathrm{~h}$ before used as nuclear donors. Using a fine pipette, a trypsinized fibroblast was transferred into the perivitelline space of an enucleated oocyte.

\section{Activation and embryos culture}

These couplets were washed with $0.3 \mathrm{M}$ mannitol solution containing $0.5 \mathrm{mM}$ Hepes, $0.1 \mathrm{mM} \mathrm{CaCl}_{2}$, and $0.1 \mathrm{mM} \mathrm{MgSO}$ for 4 times and transferred to a chamber containing two electrodes that were overlaid with fusion and activation solution. Couplets were fused/activated with a single DC pulse of $1.5 \mathrm{kV} / \mathrm{cm}$ for $30 \mu \mathrm{sec}$ using a BTX Electro-Cell Manipulator 2001 (BTX, Inc., San Diego, CA). After activation treatment, the reconstructed embryos were washed three times with NCSU-23 (Petters et al. 1993) supplemented with $4 \mathrm{mg} / \mathrm{mL}$ fatty acid free BSA (Sigma-Aldrich Corp.), and cultured with NCSU-23 supplemented with $4 \mathrm{mg} / \mathrm{mL}$ fatty acid-free BSA (Sigma-Aldrich Corp.), $5 \mathrm{mg} / \mathrm{mL}$ cytochalasin B and $10 \mathrm{mg} / \mathrm{mL}$ cycloheximide (CHX) for $4 \mathrm{~h}$ at $38.5,5 \%$ $\mathrm{CO}_{2}$ in air, and then the oocytes were cultured without chemical $\mathrm{CB}$ and $\mathrm{CHX}$ embryo medium which had been previously covered with paraffin oil in a polystyrene culture dish and equilibrated at 38.5 in an atmosphere of $5 \% \mathrm{CO}_{2}$ in air.

\section{In vitro development of cloned embryos}

After activation treatment, the cloned embryos were washed 5 times with NCSU-23 containing $4 \mathrm{mg} / \mathrm{mL} \mathrm{BSA}$, and then cultured in the same medium which had been previously covered with paraffin oil in a polystyrene culture dish and equilibrated at 38.5 in an atmosphere of $5 \% \mathrm{CO}_{2}$ in air. The rate of cleavage and blastocyst formation was assessed on days 2 and 7 , respectively (Fig. 1). 
Table 1. Effects of different donor cells on in vitro development of cloned Meishan pig embryos.

\begin{tabular}{cccc}
\hline Fibroblast cell type & No. of embryos (Repeats) & No. of cleavage $(\%)$ & No. of blastocysts $(\%)$ \\
\hline Fetal & $886(10)$ & $716(80.7 \pm 6.5)^{\mathrm{a}}$ & $140(15.6 \pm 7.1)^{\mathrm{a}}$ \\
Newborn ear skin & $950(10)$ & $740(77.5 \pm 6.8)^{\mathrm{a}}$ & $115(12.3 \pm 7.6)^{\mathrm{a}}$ \\
Adult ear skin & $1260(10)$ & $890(70.5 \pm 7.9)^{\mathrm{b}}$ & $113(8.8 \pm 9.3)^{\mathrm{b}}$ \\
\hline
\end{tabular}

Table 2. Development of cloned embryos derived from different donor cells after being transferred to surrogate gilts.

\begin{tabular}{cccccc}
\hline $\begin{array}{c}\text { Fibroblast } \\
\text { cell type }\end{array}$ & $\begin{array}{c}\text { No. of } \\
\text { surrogates }\end{array}$ & $\begin{array}{c}\text { No. of transferred } \\
\text { embryos }\end{array}$ & $\begin{array}{c}\text { No. of } \\
\text { pregnancy }(\%)\end{array}$ & $\begin{array}{c}\text { No. of } \\
\text { delivery }(\%)\end{array}$ & $\begin{array}{c}\text { Offfspring } \\
(\text { dead })\end{array}$ \\
\hline Fetal & 4 & $262.5 \pm 83.8$ & $2(50.0 \%)^{\mathrm{a}}$ & $2(50.0 \%)^{\mathrm{a}}$ & 7 \\
Newborn ear skin & 4 & $230.7 \pm 50.1$ & $2(50.0 \%)^{\mathrm{a}}$ & $1(25 \%)^{\mathrm{b}}$ & $2(2)$ \\
Adult ear skin & 4 & $270.0 \pm 82.5$ & $1(25 \%)^{\mathrm{b}}$ & $0(0.0 \%)^{\mathrm{c}}$ & 0 \\
\hline
\end{tabular}

Table 3. Comparison of birth weight of cloned piglets derived from different donor cells.

\begin{tabular}{ccccc}
\hline $\begin{array}{c}\text { Donor cell } \\
\text { type }\end{array}$ & $\begin{array}{c}\text { Fetal } \\
\text { fibroblast }\end{array}$ & $\begin{array}{c}\text { Newborn ear skin } \\
\text { fibroblast }\end{array}$ & $\begin{array}{c}\text { Adult ear skin } \\
\text { fibroblast }\left(\sigma^{\rrbracket}\right)\end{array}$ & Control $\left(\sigma^{刃}\right)$ \\
\hline No. of piglets & 7 & $2($ dead $)$ & 0 & 10 \\
Birth weight $(\mathrm{g})$ & $1230.5 \pm 138.1^{\mathrm{a}}$ & $1310.0 \pm 296.8^{\mathrm{a}}$ & 0 & $965.3 \pm 125.6^{\mathrm{b}}$ \\
\hline
\end{tabular}

\section{Embryo transfer}

Potential surrogates (Large White) weighing 100 $\mathrm{kg}$ to $150 \mathrm{~kg}$ were used as the surrogate mothers of the cloned embryos. They were checked for estrus twice a day. The SCNT embryos cultured for 16 to 20 $\mathrm{h}$ after activation were transferred to the oviduct of the naturally cycling gilts on the first day of standing estrus. Surrogates anesthesia was injected with pentobarbital sodium. The SCNT embryos (180 embryos per surrogate) were loaded into a catheter (Tyco Healthcare Group LP, MA, USA) and transferred to the oviducts of the estrous surrogate mother after midventral laparotomy. Non-return surrogates were checked for pregnancy by transabdominal ultrasound scanner (HS-101V, Honda Electonics Co., Ltd.) examination at day 25 after ET.

\section{Microsatellite analysis}

In order to confirm the genetic identity of the SCNT piglets with the donor cells, the parentage analysis was performed in piglets produced by SCNT and the surrogate recipient. The isolated genomic DNA samples obtained from each newborn piglet (ear tissue) and recipient (ear tissue) were used for microsatellite analysis and sent to a company that specializes in parentage verification for swine (Shanghai Gene Core Biotechnologies Co., Ltd.). The genomic
DNA was performed by 7 porcine-specific microsatellite markers (S0026, S0070, S0155, S0226, SW122, SW857, and SW936) labeled with the fluorescent dye carboxyfluorescein (FAM).

\section{Statistical analysis}

All percentage data were subjected to arcsine transformation in each replicate. The transformed values and numbers of cells in blastocysts were analyzed by one-way ANOVA followed by Fisher;s protected least significant difference test. A probability of $\mathrm{p}<0.05$ was considered statistically significant.

\section{Ethics statement}

All animal procedures in this study were performed according to the Chinese Animal Welfare Act and to a protocol Approved by the Hubei Academy of Agricultural Sciences.

\section{Results}

\section{Effect of the donor cells on in vitro developmental competence of cloned embryos}

As shown in Table 1, the cleavage rate and blastocyst formation rate of reconstructed embryos 


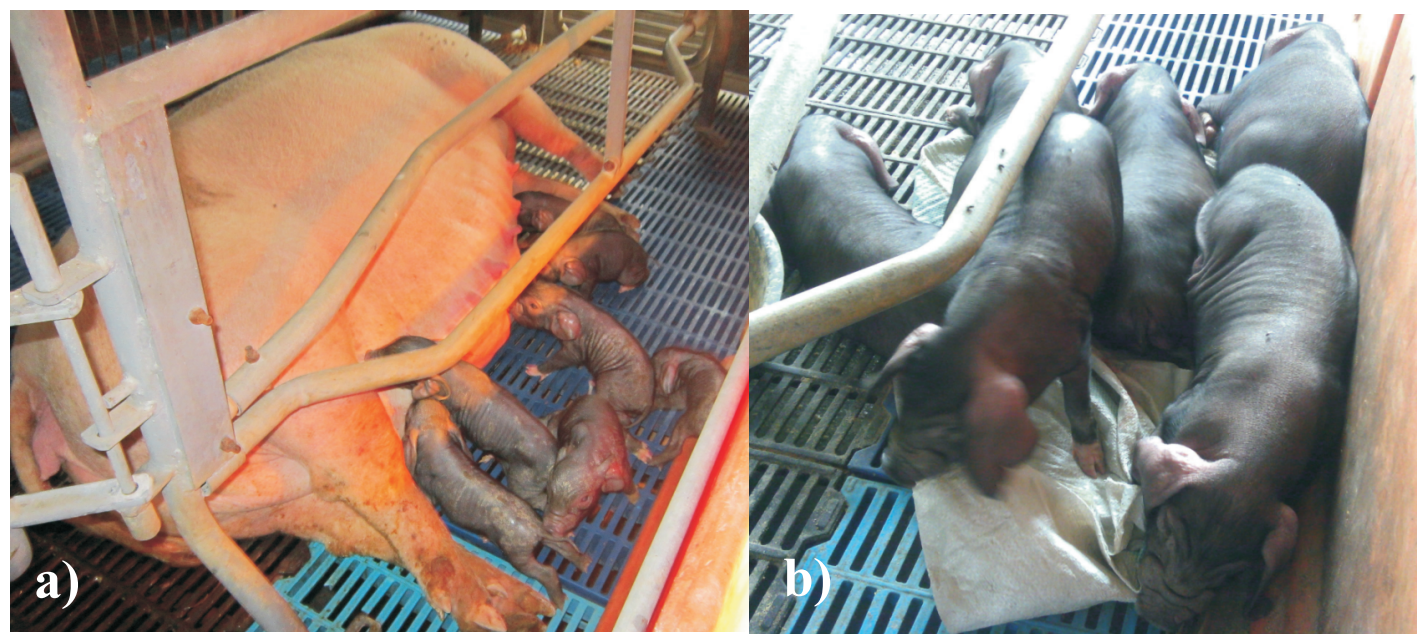

Fig. 2. Meishan pigs cloned by SCNT. Piglets derived from fetal fibroblasts (a) at 1 day of age, (b) at 30 days of age.

Table 4. Microsatellite analysis of cloned piglets derived from fetal fibroblasts.

\begin{tabular}{cccccccccc}
\hline Marker & $\begin{array}{c}\text { Surrogate } \\
\text { mother }\end{array}$ & $\begin{array}{c}\text { Fetal } \\
\text { fibroblasts }\end{array}$ & $\begin{array}{c}\text { Piglet } \\
\text { No.01 }\end{array}$ & $\begin{array}{c}\text { Piglet } \\
\text { No.02 }\end{array}$ & $\begin{array}{c}\text { Piglet } \\
\text { No.03 }\end{array}$ & $\begin{array}{c}\text { Piglet } \\
\text { No.04 }\end{array}$ & $\begin{array}{c}\text { Piglet } \\
\text { No.05 }\end{array}$ & $\begin{array}{c}\text { Piglet } \\
\text { No.06 }\end{array}$ & $\begin{array}{c}\text { Piglet } \\
\text { No.07 }\end{array}$ \\
\hline S0026 & $93 / 97$ & $91 / 101$ & $91 / 101$ & $91 / 101$ & $91 / 101$ & $91 / 101$ & $91 / 101$ & $91 / 101$ & $91 / 101$ \\
S0070 & $276 / 292$ & $263 / 292$ & $263 / 292$ & $263 / 292$ & $263 / 292$ & $263 / 292$ & $263 / 292$ & $263 / 292$ & $263 / 292$ \\
S0155 & 155 & $153 / 162$ & $153 / 162$ & $153 / 162$ & $153 / 162$ & $153 / 162$ & $153 / 162$ & $153 / 162$ & $153 / 162$ \\
S0226 & $182 / 194$ & $186 / 196$ & $186 / 196$ & $186 / 196$ & $186 / 196$ & $186 / 196$ & $186 / 196$ & $186 / 196$ & $186 / 196$ \\
SW122 & 112 & $107 / 118$ & $107 / 118$ & $107 / 118$ & $107 / 118$ & $107 / 118$ & $107 / 118$ & $107 / 118$ & $107 / 118$ \\
SW857 & 149 & 155 & 155 & 155 & 155 & 155 & 155 & 155 & 155 \\
SW936 & $94 / 109$ & $95 / 109$ & $95 / 109$ & $95 / 109$ & $95 / 109$ & $95 / 109$ & $95 / 109$ & $95 / 109$ & $95 / 109$ \\
\hline
\end{tabular}

did not significantly differ between the fetal $(80.7 \%$ and $15.6 \%)$ and newborn ear skin (77.5\% and $12.3 \%)$ fibroblast groups $(\mathrm{p}>0.05)$, but both groups exhibited significantly higher rates than the adult ear skin (70.5\% and $8.8 \% ; \mathrm{p}<0.05)$.

The cleavage and blastocyst rates were based on the number of reconstructed embryos cultured. Values with same superscript letters within a column were not significantly different $(p>0.05)$. Values with different superscripts were significantly different $(\mathrm{p}<0.05)$.

\section{Effect of the donor cell type on the implantation rate of embryos derived from $\mathrm{SCNT}$}

Reconstructed embryos derived from fetal, newborn, and adult ear skin fibroblasts were transferred to four surrogate mothers, respectively. The number of pregnancies for the fetal, newborn, and adult ear skin fibroblasts were two $(50.0 \%)$, two $(50.0 \%)$, and one $(25.0 \%)$ respectively, and the number of deliveries were two $(50.0 \%)$, one $(25.0 \%)$, and zero $(0.0 \%)$, respectively (Table 2 ). Seven and two cloned piglets were obtained from the fetal and newborn ear skin fibroblasts while no piglets were obtained with the adult ear skin fibroblasts . Because of neonatal asphyxia caused by dystocia, two neonates from the newborn ear skin fibroblasts died shortly after birth.

The birth weights of the piglets derived from the fetal and newborn ear skin fibroblasts were 1230.5 and $1310.0 \mathrm{~g}$, respectively, which were statistically insignificant $(\mathrm{p}>0.05)$, but both were significantly greater than that of the control groups $(\mathrm{p}<0.05)$ (Table 3$)$.

\section{DNA Parentage Analysis}

The Meishan piglets cloned by SCNT had black fur visibly different from the white fur of surrogate (Large White) (Fig. 2). Genetic identification was performed by microsatellite analysis of genomic DNA from each of the newborn piglets, the surrogate female, and the donor fibroblasts. Only 2, 1, and 2 heterozygous loci were observed in the 7 porcine-specific microsatellite markers of the donor cell lines from the fetal fibroblasts. The gene homozygosity of all donor cells was higher than that of the surrogate mothers (Tables 4). 


\section{Discussion}

Various types of primary transgenic or non-transgenic porcine cells were used as nuclear donors for the production of cloned embryos or piglets. But because the extent of cell differentiation is different in different types of cells, the characterization of the cells is normally restricted to the efficiency of SCNT animal production. In a previous study, Campbell et al. (2005) have reported that the oocyte quality, nuclear transfer protocol, embryo culture or recipient animal preparation, as well as the type and quality of the nuclear donor cells were all vital parameters influencing the outcome of cloning efficiency (Campbell et al. 2005). After that, some researchers demonstrated that different nuclear donor cell lines of the same cell type (fibroblasts) recovered identically from the same tissue could result in dramatically different blastocyst formation rates (Poehland et al. 2007), and they finally concluded that the developmental competence of SCNT embryos was influenced by the individual genetic characteristic of the nuclear donor cells. A study has demonstrated that differences in the expression of developmentally important genes during early embryo development may reflect the ability of donor cells to support the development of cloned bovine embryos (Beyhan et al. 2007), but the cloning efficiency whether affected by the differences in gene expression among the donor cell lines were not found.

In the past decade, the technology of SCNT has made a great progress, however the pregnancy and farrowing rate were still too low to make a rigorous assessment of the impact of nuclear donor cell types on overall SCNT success. In mouse, Thuan et al. (2010) has indicated that the cloning efficiency could be improved by the appropriate interaction between cell type and genotype (Thuan et al. 2010). In cattle, compared with newborn or fetal cells, the clones derived from adult cells aborted in the later stages of pregnancy and calves developing to term show a higher number of abnormalities (Kato et al. 2000). The cloning efficiency could be maximized by the simultaneous coordination of the donor cell type and cell cycle stage (Wells et al. 2003). However, in buffalos, cumulus cells were more efficient nuclear donor for SCNT than skin fibroblast and granulosa cell lines (Pandey et al. 2010). In sheep, Dinnyeset al. (2001) revealed breed-specific variability in terms of cloned embryo development (Dinnyes et al. 2001). Nevertheless, neither the donor cell type nor the gender significantly affects the overall efficiency of the in vitro production of SCNT sheep embryo (Hosseini et al. 2008). In the pig, it is also important to choose an appropriate donor somatic cell for the de- velopment of cloned embryos, Although several cell types have proved to be used as the donor cells, fetal fibroblasts are perceived as the most effective type among adult and fetal fibroblasts, cumulus and oviduct cells (Lee et al. 2003). Moreover, comparisons show that the donor cells derived from fetal fibroblasts remain superior to adult cells of any type in terms of reconstructed embryo development.

Our results reconfirmed the fact that the type of the donor somatic cell plays an important role in the development of nuclear transfer embryos. Moreover, these results further confirm that among the three types of donor fibroblasts choosed from Meishan pigs, fetal fibroblasts have the highest efficiency as donor cells in SCNT, while adult fibroblasts have the lowest efficiency. The cleavage rate and blastocyst formation rate of reconstructed embryos did not significantly differ between the fetal and newborn ear skin fibroblast groups, but both groups exhibited significantly higher rates than the adult ear skin. The very low efficiency of adult fibroblasts as donor cells in SCNT could be attributed to the very low cleavage rate and blastocyst formation rate. In addition, reconstructed embryos derived from fetal, newborn, and adult ear skin fibroblasts were transferred to four surrogate mothers, respectively. For the fetal, newborn, and adult ear skin fibroblasts, the number of pregnancies was two, two, and one, respectively, and the number of deliveries was two, one, and zero, respectively. Seven and two cloned piglets were obtained from the fetal and newborn ear skin fibroblasts, while no piglets were obtained with the adult ear skin fibroblasts. Two neonatuses from the newborn ear skin fibroblasts died shortly after birth because of neonatal asphyxia caused by dystocia. The birth weights of the piglets derived from the fetal and newborn ear skin fibroblasts were 1230.5 and 1310.0 $\mathrm{g}$, respectively, which were statistically insignificant, but both were significantly greater than that of the control groups. Previous studies have demonstrated that regardless of the donor age in several other different species the developmental rates of cloned embryos remain similar (Wakayama et al. 2001). However, Lee et al.(2003) indicated the donor cells of different age in pigs also have significant differences in developmental rate and birth rate (Lee et al. 2003). The possible reason for the decreased potential of fibroblasts as donor cells in producing cloned healthy live birth with increasing age may also be attributed to the differentiation status of donor cells. Fetal cells are highly undifferentiated and more amenable to reprogramming after reconstruction than differentiated cells (Lee et al. 2003). While adult animals remain a high degree of somatic cell differentiation and accumulate more genetic aberra- 
tions which reduced the developmental capacity of reconstructed embryos (Heidari et al. 2010). Therefore, adult animals are usually not the best choice as the source of the donor cells.

Previous studies have reported that various abnormal phenotypes like high birth weight may be inherited by SCNT clones (Hirayama et al. 2011). In this study, we transferred all the reconstructed embryos into crossbred Large White surrogated mothers. Comparing with non-cloned Meishan pigs the birth weight of cloned Meishan piglets was much higher. The possible explanation of this phenomenon may be different body sizes of the surrogate mothers. The body size of the surrogate mother for the cloned Meishan piglet was approximately $150 \mathrm{~kg}$, while the Meishan sow was much smaller (approximately $50 \mathrm{~kg}$ ). The surrogate mother carries fewer cloned fetuses than the Meishan sow. Thus, the cloned Meishan piglet fetuses can obtain more nutrition and large developmental space from large surrogate mothers than non-cloned Meishan piglets from Meishan inbred sow. As a result, the birth weights of the cloned Meishan piglets were significantly higher than those of non-cloned Meishan pigs. DNA parentage showed that the genotype of each litter was identical to its donor cell but different from its surrogate mother.

\section{Conclusion}

We have investigated the influence of nuclear donor cells obtained from different individual animals of different periods of life. The cloning efficiency of the fetal fibroblasts was significantly higher than those of the newborn and adult fibroblasts. The results of this study may help to identify and optimize the appropriate type of nuclear donor cells to successed in programs aiming to generate cloning pigs, which will bring benefits in terms of animal models, transgenesis, genomics and xenotransplantation.

\section{Acknowledgments}

This project was supported by China Major Program of Genetically Modified Organism for New Species Cultivation (No. 2016ZX08006002-006; No. 2014ZX08010-003) and Innovation Center for Agricultural Sciences and Technologics of Hubei Province (2011-620-001-003). This study was supported by the Project from Hubei Key Laboratory of Animal Embryo Engineering and Molecular Breeding (2013ZD120).

\section{References}

Arat S, Gibbons J, Rzucidlo SJ, Respess DS, Tumlin M, Stice SL (2002) In vitro development of bovine nuclear transfer embryos from transgenic clonal lines of adult and fetal fibroblast cells of the same genotype. Biol Reprod 66:1768-1774.

Baguisi A, Behboodi E, Melican DT, Pollock JS, Destrempes MM, Cammuso C, Williams JL, Nims SD, Porter CA, Midura P, Palacios MJ, Ayres SL, Denniston RS, Hayes ML, Ziomek CA, Meade HM, Godke RA, Gavin WG, Overstrom EW, Echelard Y (1999) Production of goats by somatic cell nuclear transfer. Nat Biotechnol 17: 456-461.

Betthauser J, Forsberg E, Augenstein M, Childs L, Eilertsen K, Enos J, Forsythe T, Golueke P, Jurgella G, Koppang R, Lesmeister T, Mallon K, Mell G, Misica P, Pace M, Pfister-Genskow M, Strelchenko N, Voelker G, Watt S, Thompson S, Bishop M (2000) Production of cloned pigs from in vitro systems. Nat Biotechnol 18: 1055-1059.

Beyhan Z, Forsberg EJ, Eilertsen KJ, Kent-First M, First NL (2007) Gene expression in bovine nuclear transfer embryos in relation to donor cell efficiency in producing live offspring. Mol Reprod Dev 74: 18-27.

Campbell KH, Alberio R, Choi I, Fisher P, Kelly RD, Lee JH, Maalouf W (2005) Cloning: eight years after Dolly. Reprod Domest Anim 40: 256-268.

Dinnyes A, King T, Wilmut I, De Sousa PA (2001) Sheep somatic cell nuclear transfer: effect of breed and culture system on embryonic and fetal development. Theriogenology 55: 264-275.

Galli C, Lagutina I, Crotti G, Colleoni S, Turini P, Ponderato N, Duchi R, Lazzari G (2003) Pregnancy: a cloned horse born to its dam twin. Nature 424: 635 .

Galli C, Lagutina I, Lazzari G (2003) Introduction to cloning by nuclear transplantation. Cloning Stem Cells 5: 223-232.

Gong G, Dai Y, Fan B, Zhu H, Wang H, Wang L, Fang C, Wan R, Liu Y, Li R (2004) Production of transgenic blastocyst by nuclear transfer from different types of somatic cells in cattle. Sei China C Life Sci 47: 183-189.

Heidari B, Shirazi A, Tajic P, Ahmadi E, Nazari H, Shams-Esfandabadi N, Ghasemzadeh-Nava H (2010) Effect of donor cell age on development of ovine nuclear transfer embryos in vitro. Zygote 18: 331-338.

Hirayama H, Sawai K, Hirayama M, Hirai T, Kageyama S, Onoe S, Minamihashi A, Moriyasu S (2011) Prepartum maternal plasma glucose concentrations and placental glucose transporter mRNA expression in cows carrying somatic cell clone fetuses. J Reprod Dev 57: 57-61.

Hosseini SM, Moulavi F, Foruzanfar M, Hajian M, Abedi P, Rezazade-Valojerdi M, Parivar K, Shahverdi AH, Nasr-Esfahani MH (2008) Effect of donor cell type and gender on the efficiency of in vitro sheep somatic cell cloning. Small Ruminant Res 78: 162-168.

Li J, Gaob Y, Petkov S, Purup S, Hyttelb P, Callesen $H$ (2014) Passage number of porcine embryonic germ cells affects epigenetic status and blastocyst rate following somatic cell nuclear transfer. Anim Reprod Sci 147: 39-46.

Kato Y, Tani T, Sotomaru Y, Kurokawa K, Kato J, Doguchi $\mathrm{H}$, Yasue H, Tsunoda Y (1998) Eight calves cloned from somatic cells of single adult Science 282: 2095-2098. 
Kato Y, Tani T, Tsunoda Y (2000) Cloning of calves from various somatic cell types of male and female adult, newborn and fetal cows. J Reprod Fertil 120: 231-237.

Lee G.S, Hyun SH, Kim HS, Kim DY, Lee SH, Lim JM, Lee ES, Kang SK, Lee BC, Hwang WS (2003) Improvement of a porcine somatic cell nuclear transfer technique by optimizing donor cell and recipient oocyte preparations. Theriogenology 59: 1949-1957.

Muenthaisong S, Dinnyes A, Nedambale TL (2011) Review of somatic cell nuclear transfer in pig. Afri J Biotechnol 10: 17384-17390.

Pandey A, Gupta SC, Gupta N (2010) Comparative Potential of Cultured Skin Fibroblast, Cumulus, and Granulosa Cell to Produce Somatic Cell Nuclear Transfer (SCNT) Preimplantation Embryos in Buffaloes (Bubalus bubalis) in Relation to Gene Expressions. Cell Reprogram 12: 357-368.

Petters RM, Wells KD (1993) Culture of pig embryos. J Reprod Fertil Suppl 48: 61-73.

Poehland R, Al-Rostum F, Becker F, Viergutz T, Brunner RM, Kanitz W, Bhojwani S (2007) Donor cell lines considerably affect the outcome of somatic nuclear transfer in the case of bovines. J Reprod Dev 53: 737-748.

Powell AM, Talbot NC, Wells KD, Kerr DE, Pursel VG, Wall RJ (2004) Cell donor influences success of producing cattle by somatic cell nuclear transfer. Biol Reprod 71: 210-216.

Prather RS, Hawley RJ, Carter DB, Lai L, Greentein L (2003) Transgenic swine for biomedicine and agriculture. Theriogenology 59: 115-123.

Shi D, Lu F, Wei Y, Cui K, Yang S, Wei J, Liu Q (2007) Buffalos (Bubalus bubalis) cloned by nuclear transfer of somatic cells. Biol Reprod 77: 285-291.
Thuan NV, Kishigami S, Wakayama T (2010) How to Improve the Success Rate of Mouse Cloning Technology. J Reprod Dev 56: 20-30.

Wakayama T, Perry AC, Zuccotti M, Johnson KR, Yanagimachi R (1998) Full term development of mice from enucleated oocytes injected with cumulus cell nuclei. Nature 394: 369-374.

Wakayama T, Yanagimachi R (2001) Mouse cloning with nucleus donor cells of different age and type. Mol Reprod Dev 58: 376-383.

Wang YS, Xiong XR, An ZX, Wang LJ, Liu J, Quan FS, Hua S, Zhang Y (2011) Production of cloned calves by combination treatment of both donor cells and early cloned embryos with 5-aza-2/-deoxycytidine and trichostatin A. Theriogenology 75: 819-825.

Wani NA, Wernery U, Hassan FA, Wernery R, Skidmore JA (2010) Production of the First Cloned Camel by Somatic Cell Nuclear Transfer. Biol Reprod 82: 373-379.

Wells DN, Laible G, Tucker FC, Miller AL, Oliver JE, Xiang T, Forsyth JT, Berg MC, Cockrem K, L'Huillier PJ, Tervit HR, Oback B (2003) Coordination between donor cell type and cell cycle stage improves nuclear cloning efficiency in cattle. Theriogenology 59: 45-59.

Wilmut I, Schnieke AE, McWhir J, Kind AJ, Campbell KH (1997) Viable offspring derived from fetal and adult mammalian cells. Nature 385: 810-813.

Zawada WM, Cibelli JB, Choi PK, Clarkson ED, Golueke PJ, Witta SE, Bell KP, Kane J, Ponce de Leon FA, Jerry DJ (1998) Somatic cell cloned transgenic bovine neurons for transplantation in parkinsonian rats. Nat Med 4: $569-574$. 